\title{
An automated procedure for laboratory and shipboard spectrophotometric measurements of seawater alkalinity: continuously monitored single-step acid additions
}

\author{
Xuewu Liu ${ }^{\mathrm{a}}$, Robert H. Byrne ${ }^{\mathrm{a}^{*}}$, Michael Lindemuth ${ }^{\mathrm{a}}$, Regina Easley ${ }^{\mathrm{a}}$, and Jeremy \\ T. Mathis ${ }^{b}$
}

${ }^{\text {a }}$ College of Marine Science, University of South Florida, $1407^{\text {th }}$ Avenue South, St. Petersburg, FL 33701, USA

bPacific Marine Environmental Laboratory, NOAA, 7600 Sand Point Way N.E. Seattle, WA 98115-6349, USA

Building on the spectrophotometric procedure of Yao and Byrne (1998), an automated analysis system has been developed for laboratory and shipboard measurements of total alkalinity at a rate of 6 samples per hour. The system is based on single-point hydrochloric acid $(\mathrm{HCl})$ titrations of seawater samples of a known volume with bromocresol purple as an indicator. The titration is continuously monitored using visible spectroscopy to guide the titration rate according to the real-time $\mathrm{pH}$ of the samples. Each titration is terminated just below the equivalence point to achieve a precision and accuracy near $1 \mu \mathrm{mol} \mathrm{kg}{ }^{-1}$. 


\section{Introduction}

Comprehensive surveys of inorganic carbon in the global ocean are essential for understanding oceanic uptake, transport, and storage of anthropogenic carbon dioxide $\left(\mathrm{CO}_{2}\right)$. Complete characterizations of the seawater $\mathrm{CO}_{2}$ system require measurements of at least two of four key system parameters: total inorganic carbon $\left(\mathrm{C}_{\mathrm{T}}\right)$, total alkalinity (Ат), carbon dioxide fugacity $\left(f \mathrm{CO}_{2}\right)$, and $\mathrm{pH}$ (Millero, 1995, 2007). $\mathrm{A}_{\mathrm{T}}$ is unique among these four in that its value does not change when $\mathrm{CO}_{2}$ is exchanged between the ocean and the atmosphere. This parameter is therefore generally considered to be one of the preferred parameters for field measurements and is a cornerstone of analytical assessments of oceanic $\mathrm{CO}_{2}$ cycling and ocean acidification.

Determinations of total alkalinity are typically based on adding acid to a seawater sample and potentiometrically measuring the resulting pH (Bockmon and Dickson, 2015). The acid may be added in a single step with direct determination of the excess acid (Culberson et al., 1970) or it may be added stepwise with algorithmic determination of equivalence points on the titration curve as proposed by Dyrssen and Sillen (1967). The multi-step procedure (Bradshaw et al., 1981; Bradshaw and Brewer, 1988; Millero et al., 1993) has been adopted as a standard operating procedure (SOP 3, Dickson et al., 2007) for shipboard measurements. The accuracy and precision of such analyses $( \pm 4$ and $\pm 2 \mu \mathrm{mol} \mathrm{kg}{ }^{-1}$; Feely et al, 2008, Millero et al., 1993), are typically poorer than the corresponding uncertainties for $\mathrm{C}_{\mathrm{T}}$ measurements ( \pm 2 and $\pm 1 \mu \mathrm{mol} \mathrm{kg}^{-1}$; Millero, 2007). The recent inter-laboratory comparison of Bockmon and Dickson (2015) showed that few of the 60 labs in the study were within $2 \mu \mathrm{mol} \mathrm{kg}{ }^{-1}$ of the assigned $\mathrm{A}_{\mathrm{T}}$ values for test samples.

Spectrophotometry-based methods (Yao and Byrne, 1998, Li et al., 2013, Martz, 2006) offer an alternative to potentiometric methods in that they avoid some of the problems associated with the glass $\mathrm{pH}$ electrodes used to monitor the acid titrations (e.g., susceptibility to large systematic errors and unpredictable drift, Wanninkhof et al., 2003). Breland and Byrne (1993) updated the potentiometric single-step alkalinity procedure of Culberson et al. (1970) by combining the speed and conceptual simplicity of the original 
method with the precision of modern spectrophotometric $\mathrm{pH}$ determinations (The precision of spectrophotometric $\mathrm{pH}$ analyses is \pm 0.0004 , (Clayton and Byrne, 1993) whereby $\mathrm{H}^{+}$concentrations are precise to $\pm 0.1 \%$ ). Yao and Byrne (1998) further developed the simplified procedure by using rapid-scan array spectrometers to continuously monitor the acid-addition process. This rapid titration procedure allows acid additions to be terminated when a seawater sample's hydrogen ion concentration just exceeds the residual bicarbonate concentration. As a result, subsequent to purging the $\mathrm{CO}_{2}$ that is evolved from protonation of bicarbonate ions, the excess acid terms are very small. The analytical precision of the alkalinity measurement is then strongly dominated by the uncertainty of the gravimetric or volumetric determinations of the amounts of sample and added acid. Through the use of gravimetric measurements and carefully standardized acid, the procedures developed by Yao and Byrne (1998) yield a precision better than $\pm 1 \mu \mathrm{mol} \mathrm{kg} \mathrm{kg}^{-1}$ for seawater alkalinity. The dependence on gravimetric procedures, however, makes this approach unsuitable for shipboard analyses and for automated measurements in any setting.

In view of the demand for accurate and precise seawater $\mathrm{A}_{\mathrm{T}}$ measurements, we developed a low-cost, simple, and robust automated spectrophotometric system for laboratory and shipboard alkalinity analyses. The procedures outlined in this work retain the advantages of single-point spectrophotometric alkalinity titrations (Yao and Byrne, 1998) and incorporate two modifications that make the method suitable for automated or at-sea analyses: use of (1) sample bottles of pre-certified volumes and (2) an automated titrator that is responsive to solution $\mathrm{pH}$. The first modification eliminates the original reliance on gravimetric determinations of seawater, while the second not only eliminates the original reliance on acid weights but also improves analytical precision and sample throughput rates.

\section{Theory}

The total alkalinity of a sample of seawater is defined as the number of moles of hydrogen ion equivalent to the excess of proton acceptors (bases formed from weak acids 
with a dissociation constant $\mathrm{K} \leq 10^{-4.5}$ at $25^{\circ} \mathrm{C}$ and zero ionic strength) over proton donors (acids with $\mathrm{K}>10^{-4.5}$ ) in $1 \mathrm{~kg}$ of sample (Dickson, 1981) :

$$
\begin{gathered}
\mathrm{AT}_{\mathrm{T}}=\left[\mathrm{HCO}_{3}^{-}\right]_{\mathrm{T}}+2\left[\mathrm{CO}_{3}^{-2}\right]_{\mathrm{T}}+\left[\mathrm{B}(\mathrm{OH})_{4}^{-}\right]_{\mathrm{T}}+\left[\mathrm{OH}^{-}\right]_{\mathrm{T}}+2\left[\mathrm{PO}_{4}^{-3}\right]_{\mathrm{T}}+\left[\mathrm{HPO}_{4}^{-2}\right]_{\mathrm{T}}+ \\
{\left[\mathrm{SiO}(\mathrm{OH})_{3}{ }^{-}\right]_{\mathrm{T}}-\left[\mathrm{H}^{+}\right]_{\mathrm{f}}-\left[\mathrm{HSO}_{4}^{-}\right]_{\mathrm{T}}-[\mathrm{HF}]_{\mathrm{T}}+\ldots}
\end{gathered}
$$

The brackets indicate constituent concentrations, with the subscripts $\mathrm{T}$ and $\mathrm{f}$ indicating total or free ion concentrations. The ellipsis represents additional minor acid or base species that are either unidentified or are present in minor amounts (e.g., $\mathrm{NH}_{3}$ and/or organic protolytes).

For a single-point titration, the alkalinity of a seawater sample that has been acidified and purged of $\mathrm{CO}_{2}$ can be written as follows (Yao and Byrne, 1998):

$$
\left.\mathrm{A}_{\mathrm{T}}=\left\{[\mathrm{HCl}]_{\mathrm{A}} \mathrm{M}_{\mathrm{A}}-\left[\mathrm{H}^{+}\right]_{\mathrm{ASW}} \mathrm{M}_{\mathrm{ASW}}-[\mathrm{HI}]_{\mathrm{total}} \Delta(\mathrm{HI}) \mathrm{M}_{\mathrm{ASw}}\right]\right\} / \mathrm{Msw}
$$

where $[\mathrm{HCl}]_{\mathrm{A}}$ is the concentration of the added acid (mol kg-1 solution); $\mathrm{M}_{\mathrm{A}}$ is the mass of acid added; $\left[\mathrm{H}^{+}\right]_{\mathrm{ASw}}$ is the excess hydrogen ion concentration in the acidified $\mathrm{CO}_{2}$-free seawater (mol kg${ }^{-1}$ (seawater)); $\mathrm{M}_{\mathrm{ASw}}$ is the mass of the acidified seawater, calculated as $\mathrm{Msw}+\mathrm{M}_{\mathrm{A}} ;[\mathrm{HI}]_{\text {total }}$ is the total concentration of a $\mathrm{pH}$ indicator in both its protonated and unprotonated forms ( $\mathrm{mol} \mathrm{kg}^{-1}$ (acidified seawater)); $\Delta(\mathrm{HI})$ is a dimensionless term that accounts for the $\mathrm{H}^{+}$gained or lost by the indicator in the final acidified seawater relative to the stock solution from which it was added; and Msw is the mass of the seawater sample $(\mathrm{kg})$. The indicator term is very small $\left(<0.2 \mu \mathrm{mol} \mathrm{kg}^{-1}\right)$ and can be ignored (Yao and Byrne, 1998). Ат can then be calculated according to the equation

$$
\mathrm{A}_{\mathrm{T}}=\left\{[\mathrm{HCl}]_{\mathrm{A}} \mathrm{M}_{\mathrm{A}}-\left[\mathrm{H}^{+}\right]_{\mathrm{ASW}} \mathrm{M}_{\mathrm{ASw}}\right\} / \mathrm{M}_{\mathrm{sw}}
$$

The $\left[\mathrm{H}^{+}\right]_{\mathrm{ASW}}$ term in Eq. $2 \mathrm{~b}$ provides proton concentrations directly in terms of moles per $\mathrm{kg}$ of seawater $\left(\mathrm{pH} \mathrm{T}=-\log \left[\mathrm{H}^{+}\right]_{\mathrm{ASW}}\right)$.

Because the gravimetric terms in Eq. $2 \mathrm{~b}$ are not directly suitable for shipboard operations, $A_{T}$ in the present work is calculated using the following equation:

$$
\mathrm{A}_{\mathrm{T}}=\left\{[\mathrm{HCl}]_{\mathrm{AVV}} \mathrm{V}_{\mathrm{A}}-\left[\mathrm{H}^{+}\right]_{\mathrm{ASW}} \mathrm{M}_{\mathrm{ASW}}\right\} / \mathrm{MsW}
$$


where $[\mathrm{HCl}]_{\mathrm{AV}}$ is the $\mathrm{HCl}$ concentration of the acid titrant in volumetric units, $\mathrm{V}_{\mathrm{A}}$ is the volume of the added acid titrant, sample mass (Msw) is obtained from volumetric measurements and solution densities (see section 3.2), and the gravimetric $\mathrm{M}_{\mathrm{A}}$ term in MAsw $\left(\mathrm{M}_{\mathrm{ASw}}=\mathrm{Msw}+\mathrm{M}_{\mathrm{A}}\right)$ is determined by measuring the volume and density of the acid $\left(\mathrm{M}_{\mathrm{A}}=\mathrm{V}_{\mathrm{A}} \sigma_{\mathrm{A}}\right.$, where $\sigma_{\mathrm{A}}$ is the density of the acid). The acid concentration $\left([\mathrm{HCl}]_{\mathrm{Av}}\right)$, in volumetric units, is determined by titrating a seawater certified reference material (a CRM with known Aт) with the acid used in the titrations (As the Aт of the CRM is known, Eq. $2 \mathrm{c}$ is solved for $\left.[\mathrm{HCl}]_{\mathrm{Av}}\right)$.

$\left[\mathrm{H}^{+}\right]_{\mathrm{ASW}}$ in Eq. $2 \mathrm{c}$ is measured spectrophotometrically through observations of bromocresol purple (BCP) absorbance ratios, $R=\lambda_{2} \mathrm{~A} / \lambda_{1} \mathrm{~A}$, where $\lambda_{2} \mathrm{~A}$ is absorbance at $589 \mathrm{~nm}$ and $\lambda_{1} \mathrm{~A}$ is absorbance at $432 \mathrm{~nm}$. Solution $\mathrm{pH}_{\mathrm{T}}$ is given as (Breland and Byrne, 1992; Yao and Byrne, 1998):

$\mathrm{pH}_{\mathrm{T}}=5.8182+0.00129(35-S)+\log ((R(25)-0.00381) /(2.8729-0.05104 R(25)))(3 \mathrm{a})$ where

$$
R(25)=R(t)\{1+0.01869(25-t)\}
$$

and $R(t)$ is the absorbance ratio measured at temperature $t$ for $29 \leq S \leq 37$ and $13^{\circ} \mathrm{C} \leq t \leq$ $32^{\circ} \mathrm{C}$ (Yao and Byrne, 1998).

\section{Materials and Methods}

\subsection{Reagents}

The titrant acid $(0.2 \mathrm{~N})$ was prepared from concentrated $\mathrm{HCl}$ (Fisher Scientific). The total ionic strength was adjusted with $\mathrm{NaCl}$ to $0.7 \mathrm{M}$. The concentration $\left([\mathrm{HCl}]_{\mathrm{Av}}\right)$, determined using certified reference materials (CRMs; Batch 109) from Dr. Andrew Dickson of the Scripps Institution of Oceanography, was $0.1970 \mathrm{~N}$ at $18{ }^{\circ} \mathrm{C}$. The $\mathrm{pH}$ indicator, bromocresol purple sodium salt, was obtained from Sigma (Sigma B-4263 Lot 104H3625) without purification. A 0.01 M BCP solution was prepared in MilliQ water. The $R$ ratio of this indicator stock solution was adjusted using $\mathrm{HCl}$ or $\mathrm{NaOH}$ solution to be about 0.3 (the targeted final $\mathrm{R}$ ratio observed after purging with $\mathrm{N}_{2}$ ), and was measured with a $0.02 \mathrm{~cm}$ cylindrical cell in an Agilent 8453 spectrophotometer. 


\subsection{Sample bottles and certification of bottle volumes}

Msw in Eq. 2c was obtained by collecting seawater samples in bottles whose volumes were known, through previous calibrations as a function of temperature. Particular attention was paid to the selection, calibration, and care of the sample bottles. Clear BOD (Biochemical Oxygen Demand) borosilicate bottles (Fisher Scientific), were chosen because their optical clarity, flanged tops, and tapered caps that facilitated spectrophotometric monitoring and elimination of bubbles and also precluded sampleloss as seawater samples warmed after collection.

To calibrate the $\mathrm{A}_{\mathrm{T}}$ sample bottles, the volume $(V)$ of each was determined based on the difference between the weight $(w)$ of the empty bottle and the weight of the bottle completely filled with MilliQ water (SOP 13, Dickson et al., 2009):

$$
w\left(\mathrm{H}_{2} \mathrm{O}\right)=w(\text { filled bottle })-w(\text { empty bottle }) .
$$

The accuracy of the weight determinations was approximately $\pm 0.01 \mathrm{~g}$. The water weight was typically $\sim 300 \mathrm{~g}$.

The mass $(m)$ of water in the bottle was calculated by correcting for air buoyancy:

$$
m\left(\mathrm{H}_{2} \mathrm{O}\right)=w\left(\mathrm{H}_{2} \mathrm{O}\right)\left(\frac{1-\rho(\text { air }) / \rho(\text { weights })}{1-\rho(\text { air }) / \rho(\text { sample })}\right)
$$

where $\rho$ is density.

The volume of water in the bottle at the calibration temperature $t_{c}\left({ }^{\circ} \mathrm{C}\right)$ was then calculated according to

$$
V\left(t_{c}\right)=m\left(\mathrm{H}_{2} \mathrm{O}\right) / \rho\left(\mathrm{H}_{2} \mathrm{O}, t_{c}\right)
$$

where the density of air-saturated water $\left(\mathrm{kg} \mathrm{m}^{-3}\right)$ is given by (Jones and Harris, 1992):

$\rho\left(\mathrm{H}_{2} \mathrm{O}, t\right)=999.84847+6.337563 \times 10^{-2}(t)-8.523829 \times 10^{-3}(t)^{2}+6.943248 \times 10^{-}$

${ }^{5}(t)^{3}-3.821216 \times 10^{-7}(t)^{4}$

for $5 \leq t \leq 40^{\circ} \mathrm{C}$.

The volume at $20^{\circ} \mathrm{C}$, for each batch of calibrated sample bottles, is calculated as (SOP 12, Dickson et al., 2007):

$$
V(20)=V\left(t_{c}\right)\left(1+9.75 \times 10^{-6}\left(20-t_{c}\right)\right)
$$


Each calibrated bottle and its paired cap were individually numbered. Care was taken to ensure that the bottles and caps were not subsequently chipped or otherwise damaged, as any change in bottle shape (volume) would have degraded the quality of the Aт analyses.

\subsection{Instrumentation}

The automated spectrophotometric alkalinity system (Fig. 1) consists of a Metrohm Dosimat 665 that is controlled with custom software through serial communication (Note: the newest model of Metrohm Dosimat could not be programmed with variable titration rate at the present time per conversation with Metrohm support and thus will not work well with applications that require variable titration rate); a stir plate with an anchoring bottle holder; an Ocean Optics LS-1 tungsten halogen light source with a blue filter; and an Ocean Optics USB4000 spectrophotometer. The Dosimat is equipped with a 5-mL exchange unit thermostated at $18^{\circ} \mathrm{C}$ (slightly lower than room temperature to prevent bubble formation in the acid line). A portable computer controls acid delivery from the titrator and records BCP absorbances, which are used to guide subsequent acid additions.

The configuration of the sample bottle in the sample bottle holder is depicted in Fig 1b. The sample holder was designed as a rectangular polyvinyl chloride (PVC) box slightly taller than the sample bottle; grey PVC plastic was used to block ambient light. Two collimating lenses with SMA connectors that were interfaced to the spectrophotometer and light source were placed about $2 \mathrm{~cm}$ above the base. A $2 \mathrm{~mm} \times 20$ mm stir bar was inserted into the sample bottle. The stir rate was adjusted to provide stable stirring at a very rapid rate of mixing. The acid tubing from the Dosimat 665 titrator was inserted just below the sample surface, while the $\mathrm{N}_{2}$ gas purging tubing was inserted above the collimating lens level so that gas flow (bubbles) would not interfere with absorbance readings. Note that if the acid tubing is inserted too low in the bottle, the relatively dense acid can penetrate the solution into the light path, whereupon the titration may be terminated prematurely. A circular plastic foam secured each sample bottle in a fixed position during the shipboard spectrophotometric measurements. The optical fibers 
of the titration system were similarly rigidly attached to the architecture of the sample cell to prevent the ship's vibration affecting spectrophotometric signals.

\subsection{Sampling and determination of sample mass}

Two types of samples were used to assess the shipboard precision, accuracy, and throughput rate of the automated $\mathrm{A}_{\mathrm{T}}$ procedure: (a) certified reference materials (CRMs) obtained from Dr. Andrew Dickson at the Scripps Institution of Oceanography, and (b) seawater collected from a range of depths in the Arctic Ocean in October 2011. All analyses were conducted on board the U.S. Coast Guard Cutter Healy (Cruise HLY1103). For comparison with our prompt shipboard measurements, the Ат of poisoned and stored Arctic seawater samples was later measured potentiometrically using the Marianda VINDTA 3C in a laboratory at the University of Alaska Fairbanks. These measurements also followed recommended best practices (Dickson et al., 2007).

Because the quality of the spectrophotometric $\mathrm{A}_{\mathrm{T}}$ analyses depends on accurate knowledge of the initial volume of each seawater sample, a rigorous protocol was followed for sample collection and handling. Each sample bottle was first rinsed three times with seawater flowing freely from a 10 L Niskin bottle through silicone tubing; each rinse volume was approximately one-third the sample-bottle volume. The tubing was then inserted to the bottom of the sample bottle, which was filled to overflowing; the overflow volume was approximately equal to the bottle volume. The sample temperature $t_{s}$ (required to ascertain bottle volume and to convert sample volume to sample mass) was measured to better than $0.1^{\circ} \mathrm{C}$ using a digital thermometer and recorded. The tubing was then jostled with an up-and-down motion in the seawater sample to ensure that no air bubbles were trapped in the bottle. Once all bubbles were cleared, the bottle cap was rinsed with seawater and the bottle was sealed. Seawater in the flange area was eliminated and the bottleneck area was dried with a Kimwipe (with a wiping action identical to that used when the bottle volume, $V\left(t_{c}\right)$, was certified in the laboratory).

In the ship's laboratory, the outside of each bottle was carefully rinsed with tap water to remove any salt and the bottle surface was wiped clean with Kimwipes. If the sample temperature changed subsequent to collection, care was taken to ensure that no 
alkalinity (seawater) was gained or lost. When the samples warmed and seawater was forced into the flanged bottle neck, care was taken to ensure no loss of sample (the bottle was maintained upright, and water within the flanged neck was not wiped away as the sample warmed).

Because the seawater samples were collected at a temperature other than the calibration temperature (i.e., $t_{s} \neq t_{c}$ ), thermal expansion or contraction of the sample bottle must be accounted for. For borosilicate bottles (SOP 12, Dickson et al., 2007),

$$
V\left(t_{s}\right)=V(20)\left(1+9.75 \times 10^{-6}\left(t_{s}-20\right)\right) .
$$

The mass of seawater sample collected in the bottle at temperature $t_{s}$ was then obtained from

$$
\operatorname{Msw}\left(t_{s}\right)=V\left(t_{s}\right) \rho_{s w}\left(t_{s}\right)
$$

where seawater density $\rho_{s w}\left(t_{s}\right)$ as function of salinity and temperature was calculated according to Millero and Poisson (1981):

$$
\begin{aligned}
& \rho(\mathrm{sw}, t)=\rho\left(\mathrm{H}_{2} \mathrm{O}, t\right)+\left(8.24493 \times 10^{-1}-4.0899 \times 10^{-3}(t)+7.6438 \times 10^{-5}(t)^{2}-\right. \\
& \left.8.2467 \times 10^{-7}(t)^{3}+5.3875 \times 10^{-9}(t)^{4}\right) \mathrm{S}+\left(-5.72466 \times 10^{-3}+1.0227 \times 10^{-4}(t)-1.6546 \times 10^{-6}(t)^{2}\right) \\
& \mathrm{S}^{1.5}+4.8314 \times 10^{-4} \mathrm{~S}^{2} .
\end{aligned}
$$

\subsection{Spectrophotometrically guided sample titrations}

For the titration procedure, the sample bottle was anchored with a bottle holder on a stir plate with a light source on one side and a spectrometer on the other (Fig. 1a). The bottle cap was removed and excess seawater was rinsed into the sample bottle with a small amount (1-2 mL) of MilliQ water. A small stir bar was inserted into the bottle, and stirring commenced. A stable stir-bar spinning at a high rate produced visible vertical mixing. The acid tube from the Dosimat titrator inserted just below the surface of the sample liquid ensures that the $\mathrm{HCl}$ is well mixed with the seawater before reaching the light path at the lower part of the bottle (Fig 1b). After a reference absorbance was recorded, $0.1 \mathrm{~mL}$ of the $\mathrm{BCP}$ stock solution was added. Acid was then delivered to the sample bottle, with the rate of acid addition being guided by continuous spectrophotometric monitoring of the seawater $\mathrm{pH}$ (Eq. 3). The initial rate of acid 
addition was $5 \mathrm{~mL}$ per min. At an $R$ value of $0.5(\mathrm{pH} \sim 5.2)$, the rate was slowed, eventually dropping to $0.1 \mathrm{~mL}$ per min. A $3 \mathrm{sec}$ delay after each rate change ensured adequate mixing of acid and sample before the next step. The titrations were terminated at $R=0.070(\mathrm{pH} \sim 4.2)$. The time to complete each titration was $\sim 1 \mathrm{~min}$. A fritted glass purging tube was then placed into the bottle above the light path and the solution was vigorously purged with $\mathrm{N}_{2}$ until $R$ was constant (0.002 unit in one minute ( $\left.5 \mathrm{~min}\right)$. Finally, the temperature $\left(0.01{ }^{\circ} \mathrm{C}\right.$ precision $)$ of the solution ( $t$ in Eq. (3b)) was measured with a digital thermometer and the final $R$ ratio obtained at this temperature was used to obtain the final $\mathrm{pH}_{\mathrm{T}}$ (Eq. 3a) used for calculation of seawater $\mathrm{A}_{\mathrm{T}}$ according to Eq. 2c. The time from the start of a titration to the completion of purging was typically $\sim 6 \mathrm{~min}$.

\section{Results and Assessment}

Precision and accuracy of the shipboard spectrophotometric alkalinity procedure were evaluated in two ways: (1) by comparison to the $\mathrm{A}_{\mathrm{T}}$ value of a certified reference material (CRM) and (2) by comparison to $\mathrm{A}_{\mathrm{T}}$ values measured by conventional shorebased methods (SOP 3, Dickson 2007) for Arctic Ocean seawater samples.

Table 2 shows the results of the CRM AT measurements made at sea over the course of 20 days with six different volume-calibrated sample bottles. As an example, consider sample bottle No. 4. The volume of this bottle had been previously determined in the laboratory as $V\left(t_{c}\right)=306.20 \mathrm{~mL}$ at $20^{\circ} \mathrm{C}$. At sea, the bottle was filled with a CRM solution at $t_{s}=19.80^{\circ} \mathrm{C}$. The volume of sample solution was therefore $306.20 \mathrm{~mL}$, and the sample mass contained in the bottle (Msw) was $313.41 \mathrm{~g}$ (Eq. 9). Over the course of the acid titration, $3.487 \mathrm{~mL}\left(\mathrm{~V}_{\mathrm{A}}\right)$ of $0.1970 \mathrm{~N} \mathrm{HCl}$ was delivered to achieve an $R$ ratio of 0.070 . After purging, the final $R(t)$ ratio was 0.230 and the temperature $t$ was $20.31{ }^{\circ} \mathrm{C}$. From Eqs. $3 \mathrm{a}$ and $3 \mathrm{~b}$, the $\mathrm{pH}$ of the final purged solution was 4.759 (i.e., $\left[\mathrm{H}^{+}\right]_{\mathrm{ASW}}=$ $\left.17.42 \times 10^{-6} \mathrm{~mol} \mathrm{~kg}^{-1}\right)$. Note that, even with a $1 \%$ error in this measurement - very large for a spectrophotometric $\mathrm{pH}$ measurement - the error in the excess acid term would be less than $0.2 \mu$ moles $\mathrm{kg}^{-1}$. The spectrophotometric $\mathrm{A}_{\mathrm{T}}$ of the CRM for this particular analysis, calculated using Eq. 2c, was therefore $2224.49 \mu \mathrm{mol} \mathrm{kg}{ }^{-1}$. 
The certified $\mathrm{A}_{\mathrm{T}}$ value was $2224.26 \mu \mathrm{mol} \mathrm{kg}{ }^{-1}$ (CRM batch 109, salinity 33.5). The overall average of the spectrophotometric Aт measurements (Table 2) was 2224.14 $\mu \mathrm{mol} \mathrm{kg}{ }^{-1}$ ( $n=6$, over 20 days) with a standard error of $0.76 \mu \mathrm{mol} \mathrm{kg}^{-1}$. The difference between the average measured $\mathrm{A}_{\mathrm{T}}$ and the certified $\mathrm{A}_{\mathrm{T}}$ was $<0.2 \mu \mathrm{mol} \mathrm{kg}{ }^{-1}$.

To further test the precision of the procedure, samples from the ship's underway system were collected in a large container to ensure homogeneity and distributed to a group of eight bottles. The sample temperature was about $3^{\circ} \mathrm{C}$. Results from eight measurements had a standard deviation of $0.7 \mu \mathrm{mol} \mathrm{kg}^{-1}$, similar to the CRM result obtained during the cruise.

Fig. 2 shows a comparison of the spectrophotometric (shipboard) and potentiometric (laboratory) Aт measurements for the Arctic seawater samples $(n=274)$. Over the entire range of observations, $\mathrm{A}_{\mathrm{T}} \sim 1900$ to $2500 \mu \mathrm{mol} \mathrm{kg}^{-1}$ and salinity from 26 to 35 , the two methods showed good agreement with no observable bias. Fig. 3 shows the differences (residuals) for the two sets of measurements. The average difference $(1 \sigma)$ was $1.2 \mu \mathrm{mol} \mathrm{kg}{ }^{-1}$.

A small amount of water ( 1 to $2 \mathrm{~mL}$ ) used to rinse off the cap changed the salinity and final mass of the samples. The effect was evaluated at different $\mathrm{R}$ ratios and salinities by adding water stepwise to the purged acidified seawater. The data obtained in this assessment are summarized in Table 3. At a low terminating $\mathrm{R}$ ratio after purging $(<0.2)$, there is a small decrease in $\mathrm{A}_{\mathrm{T}}$ (a $5 \mathrm{ml}$ of water addition decreases $\mathrm{A}_{\mathrm{T}}$ by about $0.2 \mu \mathrm{mol}$ $\mathrm{kg}^{-1}$ ). When the $\mathrm{R}$ ratio was high enough (>0.3), the residual $\mathrm{H}^{+}$is less than $10 \mu \mathrm{mol} \mathrm{kg}$ ${ }^{1}$, whereupon changes in $\mathrm{A}_{\mathrm{T}}$ for a $5 \mathrm{~mL}$ addition of water are $<0.1 \mu \mathrm{mol} \mathrm{kg}{ }^{-1}$ ). Most of our measurements were terminated at $\mathrm{R}$ about 0.3 . With $2 \mathrm{~mL}$ water additions, the change in $\mathrm{A}_{\mathrm{T}}$ due to this rinsing is smaller than $0.1 \mu \mathrm{mol} / \mathrm{kg}$, which is not observable using this method.

\section{Discussion}

The spectrophotometric Ат procedures evaluated in this work are inherently accurate and precise. The sample $\mathrm{A}_{\mathrm{T}}$ is proportional to the volume of acid used in the titration compared to the CRM. The mass of sample can generally be calculated to 
approximately $+/-0.01 \%(0.02 \mathrm{~g}$ in $300 \mathrm{~g})$. The acid delivery is precise to about $+/-0.03 \%$ $(0.001 \mathrm{ml}$ in $3 \mathrm{ml})$. The overall $\mathrm{A}_{\mathrm{T}}$ precision of the procedure is about $0.05 \%$. Our data for samples collected in the Arctic Ocean show that duplicate samples routinely agree within $1 \mu \mathrm{mol} \mathrm{kg}$. The result of CRM measurements throughout the month long cruise indicates that the measurement system does not require frequent calibration as long as the acid concentration is stable.

The automated spectrophotometric $\mathrm{A}_{\mathrm{T}}$ system requires relatively small sample volumes and offers procedural simplicity — advantages that can be especially important for work at sea. The $300 \mathrm{ml} \mathrm{BOD} \mathrm{bottles} \mathrm{with} \mathrm{the} \mathrm{tapered} \mathrm{cap} \mathrm{and} \mathrm{flanged} \mathrm{neck,} \mathrm{allow}$ accounting for thermal-expansion and full-bottle solution titrations. Conducting the titration directly in the sample bottle at near-ambient temperature (as opposed to using a separate titration cell for a thermo-equilibrated sample) also eliminates some procedural steps, thus speeding the analyses and minimizing the likelihood of sample contamination. Samples should always be measured in non-condensing conditions. Condensation on optical surfaces at very low temperatures can affect absorbance readings. Low temperature samples should be allowed about a half hour warm up time before analysis.

For the current spectrophotometric method, $\sim 1$ minute is required for each sample to be titrated to $R \sim 0.07$ (and $\sim 5$ minutes is required to purge the sample of $\mathrm{CO}_{2}$ and complete the measurement). This can be compared to about 20 minutes per sample for potentiometric-based methods (such as the Marianda VINDTA 3C). Sample rates could be further improved by integrating multiple titrators and processing multiple samples simultaneously. With four such units, the spectrophotometric $\mathrm{A}_{\mathrm{T}}$ system could process samples at a speed matching that of shipboard manual spectrophotometric $\mathrm{pH}$ measurements (i.e., 20 samples $\mathrm{hr}^{-1}$ ). For samples that differ significantly in salinity compared to a normal seawater range, a slight adjustment in the initial titration $\mathrm{R}$ ratio is needed. For lower salinity ( $\mathrm{S}$ about 20) and for fresh water, the desired $\mathrm{R}$ ratio prior to purging should be about 0.08 to 0.09 so that the final $\mathrm{R}$ ratio after purging will be stable within the range of 0.2 to 1 .

Currently there is increased interest in understanding the alkalinity contributions of unknown bases, such as those attributable to organics in coastal environments and 
oceans, such as the Arctic, that receive especially high river input. The method presented in this work is being further developed to measure alkalinity contributions from natural organics at low concentrations. Spectrophotometric titrations are particularly useful for this purpose because spectrophotometric indicators equilibrate on millisecond time scales.

\section{Acknowledgements}

We thank the crew of USCGC Healy for their excellent support during the 2011 Arctic cruise (HLY 1103), as well as the lab at the University of Alaska at Fairbanks for performing the laboratory $\mathrm{A}_{\mathrm{T}}$ analyses. We appreciate Dr. Tonya Clayton's help during the manuscript preparation for her critical comments and editorial expertise. The critical comments of two reviewers greatly improved the manuscript. The authors wish to acknowledge the support of the Ocean Acidification Program of the National Oceanic and Atmospheric Administration and NSF Grant OCE-1220110.

\section{References}

Bockmon, E.E., Dickson, A.G., 2015. An inter-laboratory comparison assessing the quality of seawater carbon dioxide measurements, Marine Chemistry 171, 36-43, doi: 10.1016/j.marchem.2015.02.002.

Bradshaw, A.L., Brewer, P.G., 1988. High precision measurements of alkalinity and total carbon dioxide in seawater by potentiometric titration -2 . Measurements on standard solutions. Mar. Chem. 24, 155-162.

Bradshaw, A.L., Brewer, P.G., Shafer, D.K., Williams, R.T., 1981. Measurements of total carbon dioxide and alkalinity by potentiometric titration in the GEOSECS program. Earth Planet. Sci. Lett. 55, 99-115.

Breland, J.B., Byrne, R.H., 1992. Determination of sea water alkalinity by direct equilibrium with carbon dioxide. Analytical Chemistry 64(19), 2306-2309, doi: $10.1021 / \mathrm{ac} 00043 \mathrm{a} 022$.

Breland, J.B., Byrne, R.H., 1993. Spectrophotometric procedures for determination of sea water alkalinity using bromocresol green. Deep-Sea Res. 40, 629-641. 
Culberson, C.H., Pytkowicz, R.M., Hawley, J.E., 1970. Seawater alkalinity determination by the $\mathrm{pH}$ method. J. Mar. Res. 28, 15-21.

Dickson, A.G., Sabine, C.L. and Christian, J.R. (Eds.) 2007. Guide to best practices for ocean $\mathrm{CO}_{2}$ measurements. PICES Special Publication 3, 191 pp.

Dickson A.G. 1981. An exact definition of total alkalinity, and a procedure for the estimation of alkalinity and total inorganic carbon from titration data. Deep-Sea Res. 28, 609-623.

Dyrssen, D., Sillen, L.G., 1967. Alkalinity and total carbonate in seawater: a plea for P-T independent data. Tellus 19, 113-121.

Feely R. A., C. L. Sabine, F. J. Millero, A. G. Dickson, R. A. Fine, C. A. Carlson, J. Toole,T. M. Joyce, W. M. Smethie, A. P. McNichol, and R. M. Key. 2008. Carbon Dioxide, Hydrographic, and Chemical Data Obtained During the R/V Knorr Repeat Hydrography Cruise in the Atlantic Ocean: CLIVAR $\mathrm{CO}_{2}$ Sections A20_2003 (22 September-20 October 2003) and A22_2003 (23 October-13 November, 2003). Ed. A. Kozyr. ORNL/CDIAC-154, NDP-089. Carbon Dioxide Information Analysis Center, Oak Ridge National Laboratory, U.S. Department of Energy, Oak Ridge, Tennessee, 46 pp. doi: 10.3334/CDIAC/otg.nd089

Jones, F.E. and Harris, G.L. 1992. ITS-90 density of water formulation for volumetric standards calibration. J. Res. Nat. Inst. Stand. Technol. 97, 335-340.

Quanlong Li, Fengzhen Wang, Zhaohui Aleck Wang, Dongxing Yuan, Minhan Dai, Jinshun Chen, Junwei Dai, and Katherine A. Hoering. 2013 Automated Spectrophotometric Analyzer for Rapid Single-Point Titration of Seawater Total Alkalinity. Environmental Science \& Technology 47 (19), 11139-11146

Martz, T. R.; Dickson, A. G.; Degrandpre, M. D. Tracer monitored titrations:

Measurement of total alkalinity. Anal. Chem. 2006, 78, 1817-1826.

Millero, F. J. 1995. Thermodynamics of the carbon dioxide system in the oceans.

Geochim. Cosmochim. Acta 59 (4), 661-677.

Millero, F. J. 2007. The Marine Inorganic Carbon Cycle. Chem. Rev. 107 (2), 308-341. 
Millero, F.J. and Poisson, A. 1981. International one-atmosphere equation of state for sea water. Deep-Sea Res. 28, 625-629.

Millero, F.J., Zhang, J.-Z., Lee, K., Campbell, D.M., 1993. Titration alkalinity of seawater. Mar. Chem. 44, 153-165.

Wanninkhof, R., T.-H. Peng, B. Huss, C.L. Sabine, and K. Lee. 2003. Comparison of Inorganic Carbon System Parameters Measured in the Atlantic Ocean from 1990 to 1998 and Recommended Adjustments. ORNL/CDIAC-140, Carbon Dioxide Information Analysis Center, Oak Ridge National Laboratory, Oak Ridge, TN, 43 pp (2003) Yao, W. and R. H. Byrne (1998). Simplified seawater alkalinity analysis: Use of linear array spectrometers. Deep Sea Res. Part I: Oceanographic Research Papers 45 (8), 13831392. 

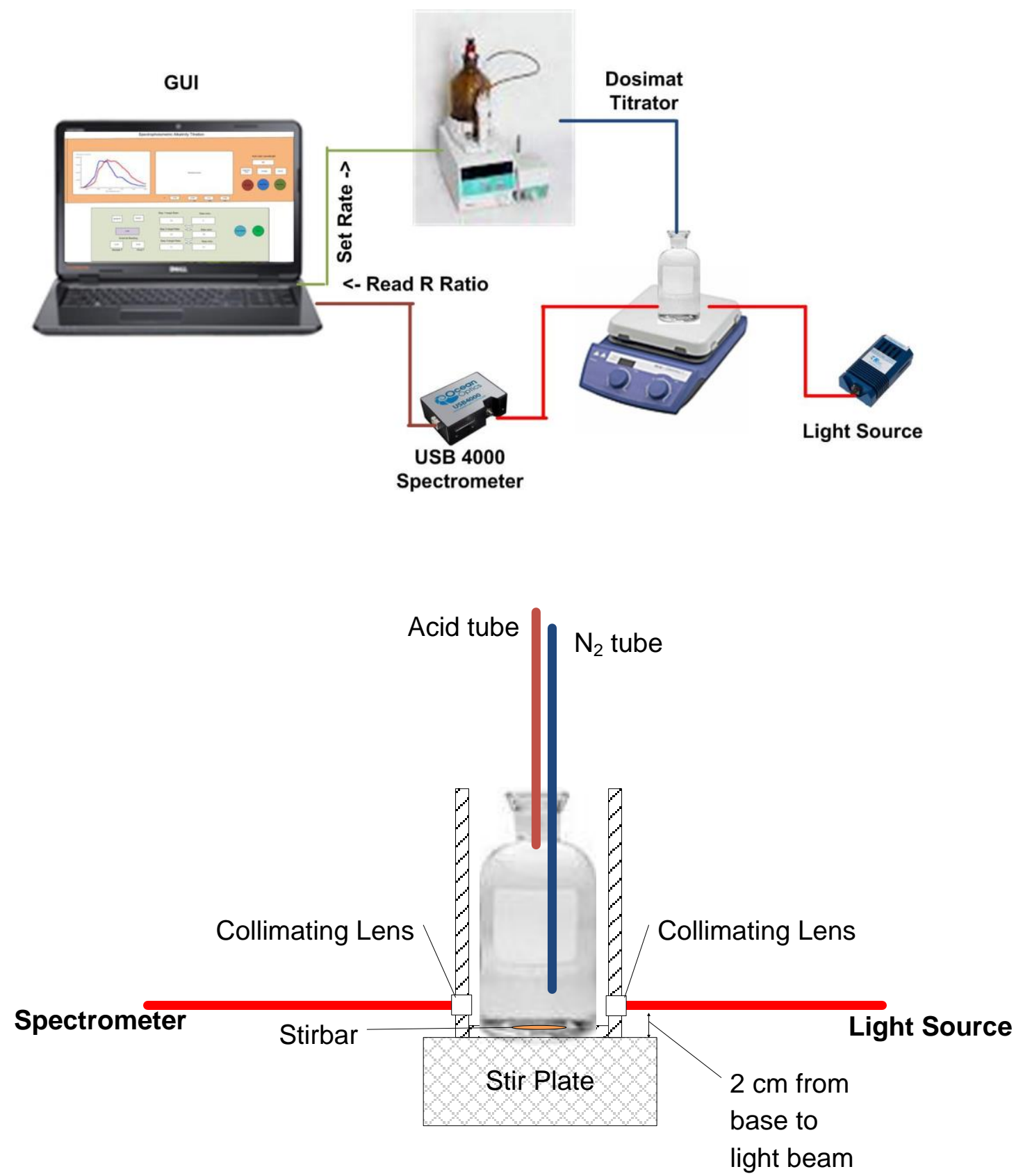

Fig. 1. The Automated Spectrophotometric Alkalinity System, ASAS. (a) A general schematic of the ASAS system. (b) Configuration of sample bottle and lightpath. 


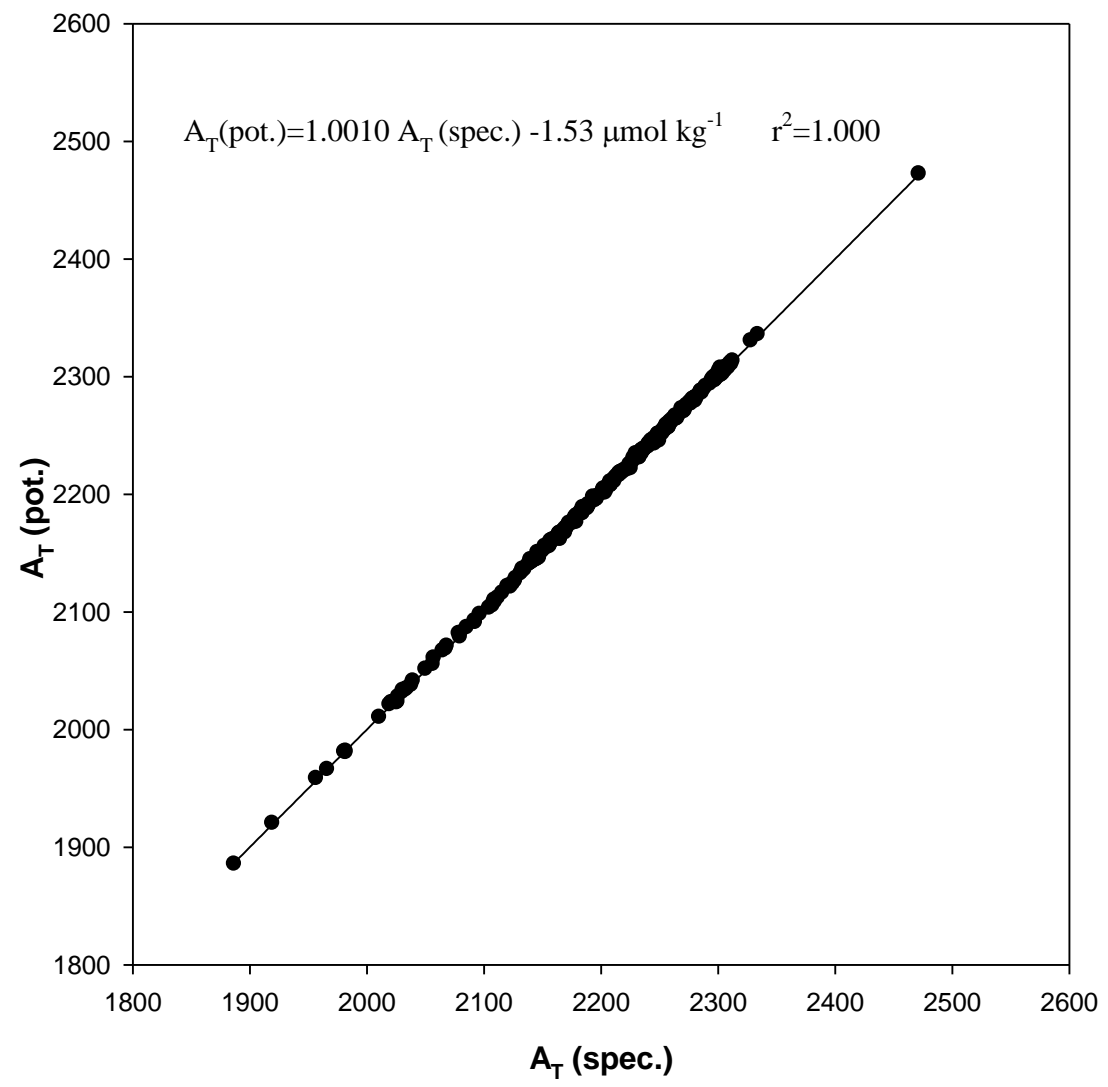

Fig. 2. Comparison of spectrophotometric $A_{\mathrm{T}}$ and potentiometric $\mathrm{A}_{\mathrm{T}}$ measured in seawater samples from the Arctic Ocean over an $\mathrm{A}_{\mathrm{T}}$ range from 1900 to $2500 \mu \mathrm{mol} \mathrm{kg} \mathrm{kg}^{-1}$ and salinity from 26 to 35 . The spectrophotometric analyses were conducted shipboard and the potentiometric analyses were conducted post-cruise in the laboratory. 


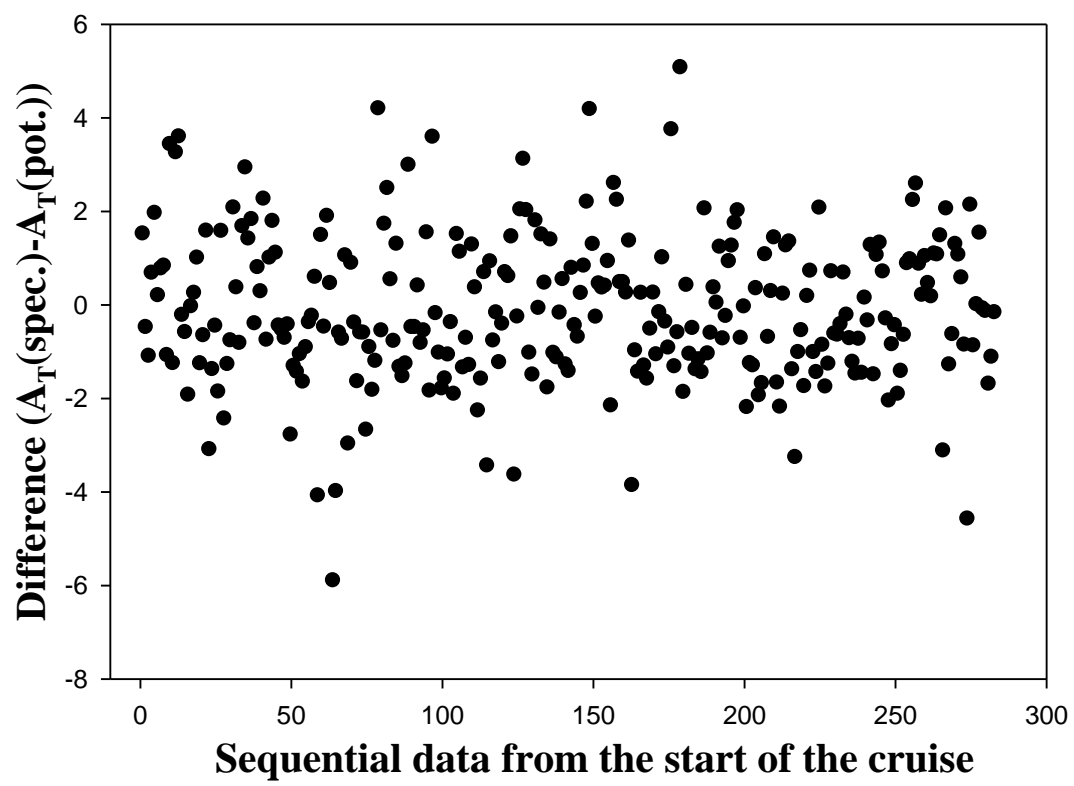

Fig. 3. Differences between spectrophotometric (shipboard) ( $\left.\mathrm{A}_{\mathrm{T}}(\mathrm{spec}).\right)$ and potentiometric (laboratory) (Ат(pot.)) measurements of $\mathrm{A}_{\mathrm{T}}$ in Arctic Ocean seawater samples. 
Table 1 Summary of Automated Spectrophotometric Alkalinity Procedures

1. Samples are collected with $300 \mathrm{~cm}^{3}$ BOD bottles. Surface samples are run first and samples are not poisoned with $\mathrm{HgCl}_{2}$.

2. Put sample in the bottle holder. Take the cap out and briefly rinse the cap with MilliQ water.

3. Take a reference spectrum of the sample.

4. Add $0.1 \mathrm{ml}$ of BCP indicator.

5. Titrate the sample using Dosimat titrator guided by monitoring the $\mathrm{R}$ ratio of the BCP. Terminate the titration at $\mathrm{R}$ ratio 0.070 for normal seawater.

6. Purge $\mathrm{CO}_{2}$ using high purity $\mathrm{N}_{2}$ gas.

7. Record sample information including sample temperature, purge ending temperature, volume of acid used, final $\mathrm{R}$ ratio. 
Table 2. Automated spectrophotometric measurements of CRM AT.

\begin{tabular}{|c|c|c|c|c|c|c|c|c|c|c|}
\hline Bottle ID & $\mathrm{t}_{\mathrm{s}}$ & $\mathrm{t}$ & $\mathrm{R}(\mathrm{t})$ & $\mathrm{V}_{\mathrm{A}}$ & $\mathrm{V}_{20}$ & $\mathrm{~V}_{\mathrm{ts}}$ & $\rho s w$ & Msw & $\mathrm{pH}$ & $\mathrm{A}_{\mathrm{T}}$ \\
\hline 20 & 22.2 & 22.80 & 0.197 & 3.493 & 306.32 & 306.33 & 1022.894 & 313.34 & 4.667 & 2223.80 \\
\hline 2 & 19.3 & 19.89 & 0.214 & 3.518 & 308.64 & 308.64 & 1023.673 & 315.95 & 4.726 & 2225.01 \\
\hline 2 & 19.8 & 20.65 & 0.205 & 3.516 & 308.64 & 308.64 & 1023.54 & 315.91 & 4.701 & 2222.89 \\
\hline 4 & 19.8 & 20.31 & 0.230 & 3.487 & 306.20 & 306.20 & 1023.54 & 313.41 & 4.756 & 2224.49 \\
\hline 7 & 23.0 & 22.70 & 0.299 & 3.504 & 308.40 & 308.41 & 1022.668 & 315.40 & 4.852 & 2224.72 \\
\hline \multirow[t]{3}{*}{4} & 20.4 & 21.30 & 0.231 & 3.486 & 306.20 & 306.20 & 1023.383 & 313.36 & 4.750 & 2223.93 \\
\hline & & & & & & & & & average & 2224.14 \\
\hline & & & & & & & & & std error & 0.76 \\
\hline
\end{tabular}

$\mathrm{V}_{20}$ is the sample-bottle calibration volume at $20^{\circ} \mathrm{C}$. The temperature of the solution at the time of sample collection is given by $t_{s} ; t$ is the temperature at the conclusion of the titration. $\mathrm{R}(\mathrm{t})$ is the final measured absorbance ratio. $\mathrm{V}_{\mathrm{A}}$ is the volume of $0.1970 \mathrm{~N} \mathrm{HCl}$ delivered over the course of the titration. $\mathrm{V}_{\mathrm{ts}}$ is the volume contained at the sample filling temperature. $\rho_{s w}$ is density of seawater. Msw is mass of seawater contained in sample bottle. The certified $A_{T}$ value (CRM batch 109) was $2224.26 \mu \mathrm{mol}$ $\mathrm{kg}^{-1}$. 
Table 3. Evaluation of effect of water rinse on alkalinity measurements

\begin{tabular}{|c|c|c|c|c|c|c|}
\hline $\mathrm{t}$ & $\begin{array}{l}\text { Water } \\
\text { added } \\
(\mathrm{mL})\end{array}$ & $\mathrm{S}$ & $\mathrm{R}(\mathrm{t})$ & $\mathrm{pH}$ & $\mathrm{H}^{+}$ & $\mathrm{A}_{\mathrm{T}}$ \\
\hline 21.1 & 0 & 36.206 & 0.1686 & 4.6079 & $2.47 \mathrm{E}-05$ & 2276.64 \\
\hline 21.1 & 1 & 36.082 & 0.169 & 4.6091 & $2.46 \mathrm{E}-05$ & 2276.62 \\
\hline 21.1 & 2 & 35.94971 & 0.1693 & 4.6101 & $2.45 \mathrm{E}-05$ & 2276.59 \\
\hline 21.1 & 3 & 35.81802 & 0.1694 & 4.6105 & $2.45 \mathrm{E}-05$ & 2276.52 \\
\hline 21.1 & 4 & 35.6873 & 0.1693 & 4.6104 & $2.45 \mathrm{E}-05$ & 2276.42 \\
\hline 21.05 & 0 & 35.55753 & 0.5272 & 5.1135 & 7.7E-06 & 2203.37 \\
\hline 21.05 & 1 & 35.4287 & 0.5275 & 5.1139 & 7.69E-06 & 2203.35 \\
\hline 21.05 & 2 & 35.30079 & 0.5274 & 5.1140 & 7.69E-06 & 2203.33 \\
\hline 21.05 & 3 & 35.17381 & 0.5282 & 5.1149 & $7.68 \mathrm{E}-06$ & 2203.31 \\
\hline 21.05 & 4 & 34.92257 & 0.5287 & 5.1156 & 7.66E-06 & 2203.30 \\
\hline 21.05 & 5 & 35.04774 & 0.5294 & 5.1160 & 7.66E-06 & 2203.28 \\
\hline 20.9 & 0 & 22.80267 & 0.4735 & 5.0837 & 8.25E-06 & 1461.57 \\
\hline 20.9 & 1 & 22.71852 & 0.474 & 5.0843 & 8.24E-06 & 1461.55 \\
\hline 20.9 & 2 & 22.635 & 0.4743 & 5.0847 & $8.23 \mathrm{E}-06$ & 1461.53 \\
\hline 20.9 & 3 & 22.55209 & 0.475 & 5.0854 & 8.21E-06 & 1461.51 \\
\hline 20.9 & 4 & 22.46978 & 0.4764 & 5.0868 & 8.19E-06 & 1461.51 \\
\hline 20.9 & 5 & 22.38807 & 0.4778 & 5.0882 & $8.16 \mathrm{E}-06$ & 1461.51 \\
\hline
\end{tabular}

